DOI: http://dx.doi.org/10.12775/szhf.2014.023

\title{
Emocja, percepcja i wyobraźnia jako rodzaje świadomości bezrefleksyjnej w filozofii Jeana Paula Sartre’a
}

Na krystalizowanie się filozofii Jeana Paula Sartre’a, szczególnie w jej wczesnym okresie, decydujący wpływ wywarła fenomenologia Edmunda Husserla. Zdaniem francuskiego myśliciela, ów wpływ okazał się w ogóle dominujący, gdy idzie o rozwój filozofii francuskiej lat trzydziestych (tzw. filozofii ducha) ${ }^{1}$.

Filozofia francuska po stu latach akademizmu nie posunęła się jeszcze dalej. Wszyscy czytaliśmy Brunschvicga, Lalande’a i Meyersona i wszyscy wierzyliśmy że Umysł-Pająk przyciąga rzeczy do swej sieci, pokrywa je białą wydzieliną, powoli pochłania i sprowadza do swej własnej substancji. Czym jest stół, skała, dom? Określonym zbiorem „treści świadomości”, pewnym porządkiem owych treści. O filozofio konsumpcyjna! A przecież nic nie mogło wydawać się bardziej oczywiste: czyż krzesło nie jest aktualną treścią mojego postrzegania,

${ }^{1}$ Ciekawą analizę filozofii francuskiej lat trzydziestych można znaleźć w książce Frédérica Wormsa La philosophie en France au XX $X^{e}$ siècle. Moments, Gallimard, Paris 2009. 
a owo postrzeganie - czyż nie jest obecnym stanem mojej świadomości? Konsumowanie, asymilowanie ${ }^{2}$.

Sartre'owska krytyka kierowała się w stronę przekonania o prymacie świadomości czystego ducha nad wszelkimi innymi dającymi się pomyśleć przejawami rzeczywistości. Wymienieni przez Sartre’a w powyższym cytacie myśliciele popadali w idealizm metodologiczny, czego skutkiem stało się drastyczne zawężenie perspektywy postrzegania świata jako zbioru przedmiotów możliwego poznania. Lekiem na wynikające $\mathrm{z}$ takich stanowisk ograniczenia stała się Husserlowska fenomenologia, która na gruncie francuskim przyjęła się bardzo szybko. Jej nowatorskie metody, zwłaszcza zasada intencjonalności, otworzyły pola możliwości teoriopoznawczych, dające się wykorzystać na wiele sposobów ${ }^{3}$.

Sartre, który jako jeden z wielu francuskich myślicieli zainteresował się myślą Husserla, nie przyjął systemu niemieckiego filozofa biernie i bezkrytycznie. Z pewnymi treściami źródłowej fenomenologii się nie zgadzał, inne radykalizowa ${ }^{4}$. Nie zmienia to jednak faktu, że metoda fenomenologiczna stała się dla niego najbardziej adekwatną metodą badawczą, wykorzystywaną na polu własnych dociekań, zwłaszcza tych dotyczących percepcji, wyobraźni i emocji.

W swoich wczesnych szkicach fenomenologicznych autor Bytu i nicości zajmował się problematyką dotyczącą istoty świadomości, a zwłaszcza zagadnieniem intencjonalności. Ważnym punktem jego filozofii stało się rozróżnienie świadomości refleksyjnej [réflexive] od bezrefleksyjnej [irréflexi-

${ }^{2}$ J. P. Sartre, Intencjonalność jako kategoria egzystencjalna, tłum. A. Milecki, [w:] Filozofia egzystencjalna, red. L. Kołakowski, K. Pomian, PWN, Warszawa 1965, s. 314.

${ }^{3} \mathrm{O}$ możliwościach rozwojowych fenomenologii na gruncie francuskim pisze m.in. Jacek Migasiński i Iwona Lorenc Zob. Fenomenologia francuska. Rozpoznania, interpretacje, rozwinięcia, red. J. Migasiński, I. Lorenc, IFiS PAN, Warszawa 2006, s. 13-18. Zob. również D. Janicaud, La phénoménologie dans tous ses états Le tournant théologique de la phénoménologie française suivi de La phénoménologie éclatée, Gallimard, Paris 2009.

${ }^{4}$ W niniejszym artykule nie będę szczegółowo opisywać, z którymi wątkami fenomenologii Sartre się zgodził, a które odrzucał, gdyż odwiodłoby mnie to od zasadniczego tematu niniejszego tekstu. Zagadnieniu fenomenologii Sartre poświęcił książkę Transcendencja Ego. Próba opisu fenomenologicznego, tłum. U. Idziak, Wyd. IFiS PAN, Warszawa 2006. Na temat rewizji myśli Husserla w filozofii Sartre’a zob. W. Gromczyński, Człowiek, świat rzeczy, Bóg w filozofii Sartre’a, Warszawa 1969; H. Puszko, Sartre: filozofia jako psychoanaliza egzystencjalna, Warszawa 1993; J. Tischner, Studia z filozofii świadomości, Kraków 2006. 
$v e]^{5}$, podanie ich typów, oddzielenie pojęć świadomość i ja, gdy zaś idzie o specyfikę własnej linii rozwoju świadomości odrzucenie Husserlowskiego ja transcendentalnego na rzecz ja transcendentnego. Sartreowska wersja fenomenologii pozbawiona jest ukrytego w głębi świadomości ja transcendentalnego, które zdaniem Husserla, miało stanowić o jedności naszych aktów apercepcyjnych. Sartre odrzucił tę ważną dla niemieckiego filozofa kategorię i stwierdził, że nie ma potrzeby wprowadzać do świadomości jakiegoś ja, które miałoby rządzić całością życia wewnętrznego, bo świadomość nie jest określona przez żadne ja, tylko przez intencjonalność.

Świadomość osiąga więc jego zdaniem zawsze jedność w swym odniesieniu do jakiegoś przedmiotu pochodzącego ze świata, a nie dzięki ja, które wedle Husserla miałoby ów proces poprzedzać. „Tymczasem - wyjaśnia Sartre w Transcendencji Ego ${ }^{6}$ - pewne jest, że fenomenologia nie musi odwoływać się do takiego jednoczącego i indywidualnego Ja. W istocie bowiem świadomość definiowana jest poprzez intencjonalność". Autor Bytu i nicości nie odrzucił jednak całkowicie tej wprowadzonej przez Husserla odzaimkowej kategorii. Jego zabieg polegał na zamianie ja transcendentalnego na ja transcendentne istniejące poza świadomością. Podstawowa różnica między Sartrem a Husserlem polegała więc na oddzieleniu świadomości od ja. Świadomość, zwana świadomością nierefleksyjną, nie nakierowuje się tu sama na siebie, jest bowiem ukonstytuowana poprzez świadomość transcendentnych przedmiotów. Jak to wyjaśnia Sartre: „świadomość jest po prostu świadomością bycia świadomością tego przedmiotu" . Świadomość bezrefleksyjna jest zaś rodzajem świadomości, pozbawionej odczucia ja. Ten typ świadomości objawia mi się na przykład, kiedy czytam książkę. W momencie czytania nie widzimy różnicy między czytaną książką i czytającym mną. Mówiąc kolokwialnie, ja zanurzam się $\mathrm{w}$ książkę i opisaną $\mathrm{w}$ niej historię, nie zastanawiając się nad tym, że łączę litery w całe wyrazy, te w wyrażenia, a wyraże-

\footnotetext{
${ }^{5}$ Trzeba podkreślić, że Sartre w swojej książce Transcendencja Ego opisuje trzy poziomy świadomości. Pierwszą, wspomnianą świadomość nierefleksyjną (irréflechie), która intencjonalnie zwrócona jest na jakiś transcendentny przedmiot, leżący w centrum jej uwagi. Jej intencja biegnie właśnie w stronę tego przedmiotu, samą siebie zaś przeżywa niejako „przy okazji”. Drugą, świadomość reflektującą (réflechissante), która podobnie jak świadomość nierefleksyjna nie posiada pozycjonalnej świadomości samej siebie, osiąga jednak pozycjonalną świadomość świadomości nierefleksyjnej. Trzecią, świadomość refleksyjną, będącą przedmiotem refleksji (réflechie), która posiada pozycjonalną świadomość samej siebie jako świadomości, nie zaś przedmiotu.
}

${ }^{6}$ J. P. Sartre, Transcendencja Ego, s. 12.

7 Tamże, s. 14. 
nia w pełne, logiczne zdania, opisujące perypetie bohaterów występujących w lekturze.

Byłem przed chwilą zaabsorbowany lekturą. Spróbuję przypomnieć sobie okoliczności mojego czytania, moje zachowanie, wersy, które czytałem. W ten sposób żywię nie tylko owe szczegóły, ale również pewną warstwę świadomości bezrefleksyjnej, skoro przedmioty mogły być dostrzeżone jedynie przez tę świadomość i skoro pozostają wobec niej względne. Nie należy tej świadomości ustanawiać jako przedmiot mojej refleksji, ale przeciwnie, chodzi o to, abym skierował moją uwagę na to, co ożywiłem, nie tracąc jej jednak z oczu, zachowując $\mathrm{z}$ nią pewien rodzaj wzajemnego porozumienia i inwentaryzując jej zawartość w sposób niepozycyjny. Wynik nie pozostawia wątpliwości: podczas gdy czytałem, była we mnie świadomość książki i bohaterów powieści, ale Ja nie zamieszkiwało tej świadomości, była to jedynie świadomość przedmiotu i świadomość niepozycyjna siebie samej. Nie ma ja w świadomości bezrefleksyjnej8.

W momencie czytania książki, kiedy utożsamiam się z występującym w niej bohaterem i przeżywam jego przygody ja po prostu nie ma. Pojawia się ono dopiero na poziomie refleksji w postaci określenia mnie jako kogoś, kto czyta tu i teraz, czyli w momencie, gdy ujmuję swój stosunek do otaczających mnie przedmiotów:

Zresztą - jak wyjaśnia Sartre w Bycie i nicości - świadomość refleksyjna [réflexive] ujmuje świadomość poddaną refleksji [réfléchie] jako swój przedmiot: w akcie refleksji formułuję sądy dotyczące świadomości poddanej refleksji: wstydzę się jej, jestem z niej dumny, pragnę jej, odrzucam ją etc. ${ }^{9}$

Z powyższych ustaleń wynika, że świadomość nierefleksyjna jest całkowicie wypełniona aktualnymi zdarzeniami, na które się nakierowuje. Może to być przytoczona powyżej jako przykład historia bohatera książki, albo widok za oknem, czy też uczucie strachu. Świadomość nierefleksyjna oznacza całkowite zatopienie się w świecie przedmiotów, bo „to one konstytuują jedność moich świadomości, prezentują swoje wartości, cechy przyciągające, czy też odpychające, podczas gdy ja zniknąłem, sam siebie unicestwiłem"10.

\footnotetext{
${ }^{8}$ Tamże, s. $18-19$.

9 J. P. Sartre, Byt i nicość, Zielona Sowa, Kraków 2007, s. 13.

10 Tamże, s. 20.
} 
Sartre wyróżnił trzy formy świadomości bezrefleksyjnej: postrzegającą [conscience perceptive], emocjonalną [conscience emotionelle] oraz wyobrażającą [conscience imageante].

Świadomość postrzegająca polega, mówiąc najprościej, na rejestrowaniu wrażeń pochodzących ze świata zewnętrznego. Sartre stwierdza, że ten rodzaj świadomości „ujmuje świat swych możliwych działań jako uporządkowany i rządzony prawami przyczynowo-skutkowymi" ${ }^{11}$. W świadomości postrzegającej nie tylko postrzegam przedmioty jako takie, lecz przede wszystkim powiązania między nimi i sposób ich układania się w większe całości.

Odwołujmy się do przykładu: pisząc te słowa, siedzę w pomieszczeniu numer 315 Wydziału Sztuk Pięknych UMK. Pierwsze, co rzuca mi się w oczy, to długie rzędy ławek przeznaczone dla studentów. Ławki te są wycinkiem, który odnosi się do większej całości, jaką jest sala numer 315, ta zaś odnosi się do jeszcze większej całości, czyli zbioru sal na drugim piętrze, a owe drugie piętro do całości, jaką jest budynek wydziału i tak dalej. Nie postrzegam przedmiotów odizolowanych od siebie, lecz takie, które odsyłają do siebie nawzajem, tworząc tym samym konglomerat różnych relacji. Przez przedmioty jestem więc otoczona ze wszystkich stron. Sartre w Transcendencji Ego stwierdza wręcz: „Jestem zatopiony w świecie przedmiotów"12. Ja nakierowuję swoją intencję na dany przedmiot, konstytuuję go i otrzymuję wgląd w ów przedmiot, lecz, co ważne, jest to wgląd tylko częściowy, bo nie widzę na przykład tylnych części ławek w końcowych rzędach czy tyłu stojącej przy ścianie szafy. Dostrzegam zatem wycinki przedmiotów, wchodzące z innymi w relacje i tworzące określoną całość ${ }^{13}$.

Wyjaśniając istotę postrzegania, Sartre w Wyobrażeniu podaje przykład sześcianu. Patrząc na sześcian, zawsze widzę tylko jedną jego stronę. Nie znaczy to jednak, że moje spostrzeżenie zostaje w ten sposób ograniczone, stopniowo bowiem ów sześcian obracając, mogę rejestrować i poznawać wszystkie, wcześniej niewidoczne dla mnie jego ściany. Sama mogę decydować, w jaki sposób chcę ów sześcian obejrzeć, na przykład od którego boku

${ }^{11}$ H. Puszko, Sartre: filozofia jako psychoanaliza egzystencjalna, Wyd. UW, Warszawa 1993, s. 116.

12 J. P. Sartre, Transcendencja Ego, s. 20.

${ }^{13}$ Do podobnych wniosków w swoich rozważaniach doszedł Maurice Merleau-Ponty. Francuski filozof stwierdza, że postrzegam przedmioty zawsze w horyzoncie innych przedmiotów. Przedmiot zawsze będzie postrzegany na tle innych rzeczy. Synteza owych horyzontów, relacje i związki między postrzeganymi przedmiotami są określone przez Merleau-Ponty’ego jako świat. 
zacząć ogląd. Dzięki nieskończonej możliwości ujmowania przedmiotu, jestem w stanie równocześnie uczyć się go oraz zapamiętywać jego własności.

Własnością postrzeżenia jest to, że przedmiot jawi się z nim w serii profili, rzutów. Sześcian uobecnia mi się, rzecz jasna; mogę go dotknąć, zobaczyć, ale widzę go zawsze tylko na jeden $\mathrm{z}$ wielu sposobów, który zarazem przywołuje i wyklucza niezliczone inne punkty widzenia. Przedmiotów trzeba się uczyć, mnożąc możliwe sposoby ujmowania ich, a sam przedmiot jest syntezą wszystkich tych przejawów. Postrzeżenie przedmiotu jest więc zjawiskiem o nieskończenie wielu aspektach. Co to znaczy dla nas? Zmusza nas to do oczekiwania ${ }^{14}$.

Wiedza o przedmiocie postrzeganym formułuje się stopniowo. Muszę „ogarnąć” wszystkie przejawy danego przedmiotu, aby się go nauczyć. Świadomość postrzegającą nazywa Sartre „świadomością bierną”, ponieważ jej działanie ogranicza się tylko do rejestracji wrażeń pochodzących ze świata zewnętrznego. Natomiast w momencie, gdy myślę o jakimś przedmiocie, powiedzmy, o tym sześcianie, od razu chwytam istotę sześcianu jako takiego. Nie muszę się go już uczyć, bo „myśl o sześcianie jest wiedzą świadomą siebie samej"15. Świat jawiący się w świadomości postrzegającej, stwierdza dalej francuski myśliciel, jest światem narzędzi, w którym rządzą prawa fizyki i związki przyczynowo-skutkowe. W świecie tym działam, wytyczam cele i staram się je osiągnąć. W chwili, gdy nie jestem w stanie wykonać jakiegoś zadania lub gdy coś sprawia mi trudność, pojawia się kolejny rodzaj świadomości bezrefleksyjnej, a mianowicie świadomość emocjonalna, która zmienia jakościowo otaczające mnie przedmioty i tworzy tzw. zabarwiony emocją świat magiczny.

Świadomości emocjonalnej poświęcił Sartre opublikowany w 1939 roku Szkic o teorii emocji ${ }^{16}$. Stosując metodę fenomenologiczną, która bada fenomeny, a nie fakty oraz inspirując się filozofią Heideggera stwierdził on, że emocja to sposób ujmowania świata i bycia w nim. Emocję określa on jako rodzaj świadomości nierefleksyjnej, ponieważ emocja jest dla niego pewną „jakością samą w sobie”, która działa bez pomocy refleksji i kierując się w stronę świata, „porusza go”. Owo poruszenie zostało przez filozofia wyjaśnione

\footnotetext{
${ }^{14}$ J. P. Sartre, Wyobrażenie. Fenomenologiczna psychologia wyobraźni, tłum. P. Beylin, PWN, Warszawa 1970, s. 22.

15 Tamże, s. 23.

${ }^{16}$ Rozprawka miała być częścią monumentalnego dzieła dotyczącego psychologii fenomenologicznej pod tytułem Psyche. Ów projekt został niestety przez Sartre’a zarzucony.
} 
na następującym przykładzie: kiedy jestem szczęśliwy, po prostu o tym wiem. Nie muszę owego uczucia szczęśliwości analizować. Nie jest potrzebne, aby świadomość utwierdzała mnie w przekonaniu, że tu teraz oto jestem szczęśliwy, bo to ja jestem szczęśliwy. Ja, określony jako podmiot, usytuowany między swoim działaniem, które przynosi mi określony zysk, a szczęściem, które w związku z tym się rodzi, nie muszę do siebie powracać i wstawiać między czyn a emocję świadomości refleksyjnej.

Podmiot, który szuka rozwiązania problemu praktycznego, znajduje się w świecie na zewnątrz, pojmuje świat w każdej chwili, poprzez każdy swój czyn [...] I nie ma takiej konieczności, żeby podmiot, pomiędzy działaniem, które mu się nie udaje, a gniewem, powracał do siebie i wstawiał pomiędzy nie świadomość refleksyjną ${ }^{17}$.

$J a$ tylko poprzez działanie $\mathrm{w}$ świecie, a ogólniej bycie $\mathrm{w}$ nim, mogę więc ów świat pojmować. Jeśli jestem szczęśliwa, to moje szczęście jest sposobem, w jaki ów świat mi się objawia. Podobnie, jeśli w danej chwili się denerwuję, to moje zdenerwowanie jest sposobem pojmowania świata w określonym „momencie”, wycinku rzeczywistości, który jawi mi się jako denerwujący. Sartre często podkreśla, że ja znajduje się w świecie, zawsze w określonej sytuacji, (czyli w możliwym ujęciu rzeczywistości), w obliczu której odczuwa określone emocje. Jego świadomość bycia w świecie zostaje w intencji emocjonalnej tak ukonstytuowana, aby mógł pojawić się jakiś odpowiadający owej świadomości przedmiot. Zmieniona przez emocję świadomość sprawia, że konstytuujący się w ten sposób przedmiot nabiera specyficznego uposażenia jakościowego. Emocje, jak to formułuje Sartre, tworzą „świat magiczny”. Francuski filozof ilustruje powyższą tezę następującym przykładem: wyobraźmy sobie, że sięgam po winogrono, ale nie mogę go zerwać. Stwierdzam przy tym, że zapewne jest ono niedojrzałe i się oddalam. Magicznie nadaję więc winogronom pewną jakość. Odgrywam, jak to określa Sartre, „komedię”. Jeśli podana tu jako przykład sytuacja dodatkowo wzbudzi we mnie, powiedzmy, irytację, to otworzy się przede mną magiczny świat zabarwiony emocją. Relacja pomiędzy światem rzeczywistym a magicznym wygląda więc następująco: świat rzeczywisty to moje istnienie faktyczne, czyli pierwotne. Emocja w określonym momencie zabarwia wycinek owego świata rzeczywistego, tj. nadaje mu pewne cechy i jakości, a wówczas wznosi się on na poziom magiczny. Tak

${ }^{17}$ J. P. Sartre, Szkic, o teorii emocji, s. 69. 
pojmowana emocja realizuje w ludzkim istnieniu określony cel, dokonując jego zabarwienia. Nie jest żadnym zakłóceniem w organizmie, lecz jakością, która w sposób nierefleksyjny określa mój sposób bycia w świecie.

Ostatnim rodzajem świadomości bezrefleksyjnej jest wyobraźnia. Opisowi tego zagadnienia francuski myśliciel poświęcił opublikowane w 1936 roku dziełko Wyobraźnia (L'imagination), które stanowiło krytykę klasycznych poglądów empirystów i racjonalistów na charakter i rolę wyobraźni. Sartre odrzucił rozważania klasycznej psychologii na rzecz fenomenologicznego sposobu wyjaśnienia interesującego go zjawiska ${ }^{18}$. Owocem zastosowania tej metody była wydana cztery lata później obszerna książka Wyobrażenie. Fenomenologiczna psychologia wyobraźni.

Jak już wcześniej zaznaczyłam, świadomość postrzegająca zakłada istnienie przedmiotu. Jej działanie polega zaś na biernej rejestracji przedmiotów: ich cech, własności oraz wzajemnych relacji. Świadomość wyobrażeniowa funkcjonuje w sposób odwrotny do postrzegania, zakłada mianowicie nieistnienie przedmiotów. Fakt, że przedmiot powstały na mocy wyobraźni nie istnieje, nie neguje ważnej dla Sartre’a zasady intencjonalności. Świadomość wyobrażająca również jest świadomością czegoś, tyle że przedmiot powstały w wyniku wyobrażenia jest uznany za nieobecny i nierzeczywisty. „Wyobraźnia - stwierdza Sartre - zakłada świat rzeczywisty i zarazem odwraca się od niego, neantyzuje go, konstytuując swój przedmiot na marginesie czy tle realnego świata" ${ }^{19}$. Francuski filozof uważa zatem, że świadomość ustosunkowuje się do tego samego przedmiotu na dwa różne sposoby. Świadomość postrzegająca zakłada jego istnienie, a wyobrażająca - nieistnienie. Mówiąc najprościej, awersem świadomości jest tu postrzeganie, a jej rewersem - wyobrażanie $^{20}$.

${ }^{18}$ Podobną krytykę przeprowadza Sartre podczas badań charakteru emocji. W tym wypadku francuski filozof odrzuca klasyczne teorie emocji m.in. Jamesa, Janeta i Wallona, stawiając na ich miejscu fenomenologiczną metodę badań. zob. J. P. Sartre, Szkic z teorii emocji, tłum. R. Abramciów, Kraków 2006.

${ }^{19}$ J. P. Sartre, Wyobrażenie. Fenomenologiczna psychologia wyobraźni, s. 160.

${ }^{20}$ Sartréowską koncepcją wyobraźni jako nicościowania świata zainspirował się francuski filozof i krytyk literacki Roland Barthes. W swojej rozprawce Światło obrazu, dotyczącej fotografii, zastanawia się m.in. nad tym, dlaczego niektóre fotografie są lepsze i ciekawsze od innych. Francuski myśliciel stwierdza, że zdjęcie, które przykuwa naszą uwagę, musi pobudzać wyobraźnię. Taka fotografia jest żywa i potrafi przenieść widza do świata wyobrażeniowego. Barthes zauważa, że fotografia kryje w sobie dwa aspekty: świat rzeczywisty, czyli zdjęcie, na które patrzymy, oraz świat wyobrażeniowy, czyli naszą interpretację owego zdjęcia. Ciekawa, przykuwająca uwagę fotografia jest wytworem, w którym splata się postrzeganie i wyobraża- 
Skoro wyobrażenie zakłada nieistnienie przedmiotu, to w samej swej strukturze musi ono zawierać tezę nicościującą. Sartre mówi tutaj o podwójnej negacji. Wyobrażenie najpierw jest nicościowaniem świata (ale tylko wtedy, kiedy nie jest to świat, w którym przedmiot wyobrażony byłby teraz dany jako aktualny przedmiot postrzeżenia), potem zaś następuje nicościowanie przedmiotu wyobrażenia (o tyle, o ile jest konstytuowany jako nieobecny czy też niezaktualizowany).

Sartre zaznacza, że nie można mieszać postrzegania i wyobrażania, gdyż, jak pisałam wcześniej, są to dwie oddzielne strony świadomości. Między obiema formami świadomości zachodzi jednak związek. Aby móc sobie wyobrazić, dajmy na to wspomniany wcześniej sześcian, muszę wiedzieć jak on wygląda, jakie są jego cechy i własności. Wiedzę czerpię z tego, czego nauczyłam się w sferze postrzegania, w której stopniowo poznawałam, uczyłam się i zapamiętywałam, czym ów sześcian jest. Przytoczmy jeszcze raz ważne słowa Sartrea: wyobraźnia neantyzuje świat „konstytuując swój przedmiot na marginesie czy tle realnego świata" (podkr. M. Ch.). Aby móc coś sobie wyobrazić, muszę zatem dysponować pewną wiedzą na dany temat. Z wyobrażenia nie nauczę się niczego, czego uprzednio nie wiedziałam. Mogę oczywiście wyobrazić sobie pewien twór, który nie istnieje w świecie rzeczywistym, powiedzmy pegaza. Pegaza tego nigdy nie spostrzegę w sytuacji realnej, jestem jednak w stanie wyobrazić go sobie, ponieważ mogę połączyć ze sobą różne elementy, które kiedyś postrzegłam i się ich nauczyłam, łącząc, w tym konkretnym wypadku, konia ze skrzydłami. Dwa zupełnie niepasujące do siebie elementy, które znam, bo kiedyś je zobaczyłam w moim wyobrażeniu, dają mi obraz tego mitycznego stwora. Zasadne jest zatem stwierdzenie, że świadomość może wyobrażać o tyle, o ile znajduje się, mówiąc po Sartre’owsku „W-sytuacji-w-świecie” ${ }^{21}$. Dzięki owemu znalezieniu się „,W sytuacji w świecie”, wyobraźnia jest w stanie konstytuować przedmioty nierzeczywiste. Sartre przejrzyście rekonstruuje związek między dwiema, pozornie nieskończenie odległymi od siebie sferami: rzeczywistości świata i nierzeczywistości wyobrażenia. Nierzeczywiste przedmioty tworzone są przez świadomość z jakiegoś punktu widzenia. Świadomość jest w stanie w sposób

nie. „Dobre zdjęcie” według Barthesa to takie, która uruchamia naszą świadomość wyobrażeniową, czyli zaprasza nas do uczestnictwa w skrywanej w owym zdjęciu przygody. Zob. R. Barthes, Światło obrazu. Uwagi o fotografii, tłum. J. Trznadel, KR, Warszawa 1996.

${ }^{21}$ W Wyobrażeniu Sartre pisze, że sytuacje to „różne sposoby bezpośredniego ujęcia rzeczywistości jako świata”. Zob. J. P. Sartre, Wyobrażenie, s. 165. 
wolny tworzyć swoje wyobrażenia, ale negacja świata, jaka zachodzi w wyobrażeniu, musi się jednak odbyć na tle świata i w związku z tym jest tłem ${ }^{22}$.

Sartre, porównując ze sobą świadomość wyobrażającą ze świadomością postrzegającą, twierdzi, że wyobrażenie niczego nie nas uczy i nigdy nie daje wrażenia nowości. Wyobrażony przedmiot zawsze jest dany w całości (wspomniany wcześniej wyobrażony sześcian nie objawia jednej ze swych stron, lecz wszystkie od razu). W procesie wyobrażania nie ma ryzyka i oczekiwania. $\mathrm{W}$ zamian za to jest pewność, bo w przeciwieństwie do postrzeżenia (a konkretniej: złudzeń zmysłowych) wyobrażenie nigdy mnie nie myli. Sartre określa postawę wobec przedmiotu wyobrażenia jako obserwację pozorną, ponieważ zajmujemy tu pewną postawę obserwacyjną, ale jest to obserwacja, która o niczym nie powiadamia ${ }^{23}$. Francuski filozof zaznacza jednak, że przedmioty dane w wyobraźni pozbawione są całego bogactwa hodologicznego, charakterystycznego dla świadomości percepcyjnej i konstytuującego charakterystykę realnego świata. Zestaw cech, jakie posiadają wyobrażone przedmioty, ogranicza się tu do tych, które zostały wyobrażone. Co więcej, wszystkie one zjawiają się natychmiastowo. Nie ma przy tym potrzeby dokonywania jakiegokolwiek oglądu przedmiotu w celu jego poznania tak, jak przy percepcji.

Należy jeszcze zaznaczyć, że Sartre nie traktuje wszystkich trzech rodzajów świadomości nierefleksyjnej na równi. Wymienione rodzaje świadomości ustawia w następującej hierarchii. Najniżej ocenia świadomość emocjonalną, gdyż jest ona określana przez niego jako przepełniona złą wiarą degradacja rzeczywistości, a nawet ucieczka od rzeczywistości w zabarwiony emocją świat magiczny. Większą wartość przedstawia świadomość postrzegająca, która podobnie jak emocjonalna, jest całkowicie zanurzona w realnym świecie, lecz od niego nie ucieka. Najbardziej ceni sobie Sartre świadomość wyobrażającą, choć w Wyobrażeniu „zachwala” on realistyczny charakter ja-

\footnotetext{
${ }^{22}$ Należy jednak zaznaczyć, że Sartre twierdził początkowo, iż trzy wymienione przez niego rodzaje świadomości są od siebie radykalnie oddzielone. Francuski filozof zakładał na przykład, że wyobraźnia zadziała tylko wtedy, kiedy nie będzie postrzegania i odwrotnie: postrzeganie nie pozwala na istnienie wyobrażenia. Działanie jednego rodzaju świadomości nierefleksyjnej po pierwsze uniemożliwia działanie drugiej, a po drugie nie może mieć żadnego wpływu na inny rodzaj świadomości z bardzo prostego powodu, otóż istotą świadomości jest wedle Sartre’a wolność, a to oznacza, że, po pierwsze, jeden rodzaj świadomości nie może być spowodowany innym rodzajem (bowiem wyłaniają się one z nicości), a po drugie, że jeden rodzaj świadomości nie ma żadnego wpływu na pozostałe (są one od siebie niezależne).

${ }^{23}$ J. P. Sartre, Wyobrażenie. Fenomenologiczna psychologia wyobraźni, s. 27.
} 
wiących się w postrzeżeniu przedmiotów (są "giętkie” i „masywne”), przy których przedmioty wyobrażone wydają się ubogie. Mimo to, najbardziej spośród wszystkich świadomości nierefleksyjnych ceni Sartre właśnie świadomość wyobrażająca, bo tylko ona jest pozbawioną złej wiary spontaniczną, wolną i czystą twórczością.

Należy jeszcze zaznaczyć, że powyższe rozważania dotyczące wyobraźni wykorzystał francuski filozof w swoim najważniejszym dziele pt. Byt i nicość, w którym proces wyobrażania połączył z kolejnym niezwykle istotnym pojęciem transcendowania ku. Jak pamiętamy, swoje późniejsze rozważania oparł Sartre na dwóch głównych pojęciach o proweniencji Heglowskiej: bytu-w-sobie oraz bytu-dla-siebie. W jego koncepcji na bazie bytu-w-sobie tworzy się byt-dla-siebie. Podmiotowość nie jest tu niczym innym, aniżeli świadomością dokonującą negacji bytu w sobie.

Sposób rozumienia dwóch podstawowych kategorii, bytu (être) i nicości (néant), przejmuje Sartre również od Hegla. Nicością jest wszystko to, co było, bo już nie jest oraz to, co będzie, bo jeszcze tego nie ma. To, co było i to, co będzie możemy przywołać do istnienia albo poprzez naszą pamięć albo dzięki wyobraźni. Nie istnieje zatem punkt czasowy jako coś tu i teraz. Rzeczywistość jest albo przeszłością albo przyszłością, czyli po prostu nicością. Takie rozumienie świata zmysłowego możliwe jest tylko wtedy, kiedy czas pojmujemy za Husserlem jako plamę trwania. Nie ma jakiegoś oderwanego punktu tu i teraz. Będąc w świecie, czyli w pozycji „jest”, ja nieustannie powołuję do istnienia coś, co samo w sobie nie jest, czyli nicuję świat, w którym żyję. Rdzeniem mego bycia tu oto (Sartre używa Heideggerowskiego terminu Dasein zamiennie z terminem „ludzka rzeczywistość” [réalité humaine]) jest byt-sam-w-sobie (lêtre-en-soi), pojmowany jako trwanie w ogóle. Treścią tego mojego bycia oto (Dasein) są wszystkie płynące ze świata wartości, zjawiska itp. Tu pojawia się druga obok bytu-w-sobie ważna kategoria głównego dzieła Sartrea, a mianowicie byt-dla-siebie (lềtre-pour-soi).

Byt-dla-siebie nie jest bytem-w-sobie i nie mógłby nim być; wszak jest jedynie możliwą, relacją do bycia-w-sobie; jest on nawet jedyną możliwą relacją do bycia-w-sobie, jako że z każdej strony toczony jest bytem-w-sobie. Wymyka mu się jedynie dlatego, że jest niczym i nic go od niego nie oddziela. Byt-dla-siebie jest fundamentem każdej negatywności i każdej relacji, on jest relacją ${ }^{24}$.

\footnotetext{
${ }^{24}$ J. P. Sarte, Byt i nicość, s. 452.
} 
Byt-w-sobie po prostu jest. Stanowi podstawę tego, by coś mogło zaistnieć jako byt-dla-mnie. Byt-w-sobie uobecnia się tylko w procesie nadawania istnienia jakiemuś bytowi-dla-siebie. Nie jest możliwe odizolowanie bytu-w-sobie od bytu-dla-siebie. Nie znajdę bytu-w-sobie w czystej postaci, bo nie mogę samego siebie odizolować od świata, w którym żyję. Byt-w-sobie zawsze będzie przesłonięty bytem-dla-siebie, czyli wszystkimi doświadczeniami płynącymi z zewnątrz. Moje życie polega na nieustannej ucieczce od bytu-w-sobie do form bytu-dla-siebie, ale obie formy bytu mogą istnieć tylko we wzajemnym związku.

Byt-dla-siebie jako nicościowanie bytu-w-sobie objawia się w czasie jako ucieczka ku [fuite vers]. Przekracza on w istocie swą faktyczność - czy to jako byt dany, czy przeszły, czy też ciało - w kierunku bytu-w-sobie, którym byłby, gdyby mógł być swoim własnym fundamentem ${ }^{25}$.

Owa nicująca ucieczka została przez Sartre’a określona mianem transcendowania. Człowiek nieustannie ucieka: albo poprzez wspominanie czegoś, co już było, albo poprzez wyobrażanie sobie czegoś, co dopiero nastąpi. Transcendując, wykracza z bytu w nicość. Owo wykraczanie jest projektowaniem zbioru cech, wartości, które tworzą jego rzeczywistość i jego samego, czyli po prostu esencję. Można powiedzieć, że byt-w-sobie jest egzystencją/ludzką rzeczywistością, a byt-dla-siebie esencją/oczekiwaną sytuacją w świecie, natomiast związek obu form ma charakter dialektyczny. Związek między bytem-w-sobie a bytem-dla-siebie dokonuje się właśnie poprzez transcendowanie. Mogę transcendować do przodu, poprzez oczekiwanie na coś lub wyobrażanie sobie czegoś. Nie jestem jednak w stanie przewidzieć przyszłości, co napawa mnie egzystencjalnym lękiem. Ja tu i teraz, byt-w-sobie, wyobrażam sobie siebie jako tego, którym jeszcze nie jestem. W miejsce owego oczekiwania tego jakim będę, wślizguje się nicość, która objawi się we właściwym czasie. Wedle Sartre’a umiejętność transcendowania wyznacza istotę bycia człowiekiem.

Wczesne badania francuskiego myśliciela dotyczące zagadnienia świadomości nierefleksyjnej miały przybliżyć najważniejszą kwestię dotyczącą istoty człowieczeństwa. Dla francuskiego filozofa bardzo istotna jest teza, że człowiek żyje w świecie, a wartości płynące ze świata zmieniają go.

25 Tamże, s. 451-452. 


\title{
Bibliografia
}

Barthes R., Światło obrazu. Uwagi o fotografii, tłum. J. Trznadel, KR, Warszawa 1996. Fenomenologia francuska. Rozpoznania, interpretacje, rozwinięcia, red. J. Migasiński, I. Lorenc, IFiS PAN, Warszawa 2006.

Gromczyński W., Człowiek, świat rzeczy, Bóg w filozofii Sartre’a, Warszawa 1969.

Janicaud D., La phénoménologie dans tous ses étatsLe tournant théologique de la phénoménologie française suivi de La phénoménologie éclatée, Gallimard, Paris 2009. Puszko H., Sartre: filozofia jako psychoanaliza egzystencjalna, Warszawa 1993.

Sartre J. P., Byt i nicość, Zielona Sowa, Kraków 2007.

Sartre J. P., Intencjonalność jako kategoria egzystencjalna, tłum. A. Milecki, [w:] Filozofia egzystencjalna, red. L. Kołakowski, K. Pomian, PWN, Warszawa 1965.

Sartre J. P., Szkic z teorii emocji, tłum. R. Abramciów, Kraków 2006.

Sartre J. P., Transcendencja Ego. Próba opisu fenomenologicznego, tłum. U. Idziak, Wyd. IFiS PAN, Warszawa 2006.

Sartre J. P., Wyobrażenie. Fenomenologiczna psychologia wyobraźni, tłum. P. Beylin, PWN, Warszawa 1970.

Tischner J., Studia z filozofii świadomości, Kraków 2006.

Worms F., La philosophie en France au XX siècle. Moments, Gallimard, Paris 2009.

\begin{abstract}
Emotion, Perception and Imagination as Types of Pre-reflective Consciousness in Jean Paul Sartre's Philosophy
\end{abstract}

The main topic of the article is the issue of pre-reflective consciousness, which was Sartre's subject matter is an early phase of his work, when he was inspired by Husserl's fenomenology. Sartre distinguished three types of pre-reflective consciousness: perception, imagination and emotion. In my article I try to explain essence of abovementioned types of consciousness, point their features and define relations between them.

Key words: Fenomenology, imagination, emotion, perception, Sartre, Husserl 